\title{
Presumptive treatment of fever cases as malaria: help or hindrance for malaria control?
}

\author{
Roly D Gosling*1, Christopher J Drakeley ${ }^{1}$, Alex Mwita ${ }^{2}$ and \\ Daniel Chandramohan ${ }^{1}$
}

Address: ${ }^{1}$ Department of Infectious and Tropical Diseases, London School of Hygiene and Tropical Medicine, Keppel Street, London, WC1E 7HT, UK and ${ }^{2}$ National Malaria Control Program, Ministry of Health, P.O.Box 9083, Dar es Salaam, Tanzania

Email: Roly D Gosling* - Roly.gosling@gmail.com; Christopher J Drakeley - Christopher.drakeley@lshtm.ac.uk; Alex Mwita - mwita@nmcp.go.tz; Daniel Chandramohan - daniel.chandramohan@lshtm.ac.uk

* Corresponding author

Published: 16 July 2008

Malaria Journal 2008, 7:132 doi:10.1186/1475-2875-7-132
Received: 8 April 2008

Accepted: 16 July 2008

This article is available from: http://www.malariajournal.com/content/7/1//32

(C) 2008 Gosling et al; licensee BioMed Central Ltd.

This is an Open Access article distributed under the terms of the Creative Commons Attribution License (http://creativecommons.org/licenses/by/2.0), which permits unrestricted use, distribution, and reproduction in any medium, provided the original work is properly cited.

\begin{abstract}
Background: Malaria incidence has been reported to be falling in several countries in sub-Saharan Africa in recent years. This fall appears to have started before the widespread introduction of insecticide-treated nets. In the new era of calls to eliminate and eradicate malaria in sub-Saharan Africa, exploring possible causes for this fall seem pertinent.

Presentation of the hypothesis: The authors explore an argument that presumptive treatment of fever cases as malaria may have played a role in reducing transmission of malaria by the prophylactic effect of antimalarials and their widespread use. This strategy, which is already in practise is termed Opportunistic Presumptive Treatment (OPT).

Testing the hypothesis: Further comparison of epidemiological indicators between areas with OPT and more targeted treatment is required. If data suggest a benefit of OPT, combining long acting antimalarials that have an anti-gametocyticidal activity component plus using high levels of vector control measures may reduce transmission, prevent resistant strains spreading and be easily implemented.

Implications of the hypothesis: OPT is practised widely by presumptive treatment of fever in health facilities and home management of fever. Improving diagnosis using rapid diagnostic tests and thus reducing the number of doses of antimalarials given may have counter intuitive effects on transmission in the context of elimination of malaria in high to moderate transmission settings.
\end{abstract}

\section{Background}

There is an increasing body of evidence suggesting that the burden of malaria in sub-Saharan Africa has been decreasing over the past decade and continues to do so (see table 1) [1-7]. The causes of this decline are unclear yet with the current calls for elimination and eradication of malaria[8] the identification of factors causing this decrease, in par- ticular those related to control strategies, would seem paramount.

To date the decrease in malaria transmission has been documented in a number of countries including Kenya[2], Tanzania[3,4], Mozambique[5], Swaziland[5], South Africa[5], Guinea Bissau[6] and Eritrea[7]. The 
Table I: Summary of studies describing reduction in malaria in sub-Saharan Africa

\begin{tabular}{|c|c|c|c|c|}
\hline $\begin{array}{l}\text { Country } \\
\text { /regionreference }\end{array}$ & $\begin{array}{l}\text { Years of } \\
\text { study }\end{array}$ & $\begin{array}{l}\text { Measure of } \\
\text { reduction }\end{array}$ & $\begin{array}{l}\text { Reported } \\
\text { reduction }\end{array}$ & $\begin{array}{l}\text { Reported } \\
\text { Reasons }\end{array}$ \\
\hline Sub-Saharan Africal & $\begin{array}{l}1985 \text { to } 1999 ; 2000 \text { to } \\
2007\end{array}$ & $\begin{array}{l}\text { Parasite prevalence } \\
\text { abstracted from over } 2,000 \\
\text { sources }\end{array}$ & I5\% (average) reduction & No reason given \\
\hline Coastal Kenya 2 & 1999 to 2007 & $\begin{array}{l}\text { Malaria specific hospital } \\
\text { admissions }\end{array}$ & $\begin{array}{l}63 \%, 53 \% \text { and } 28 \% \\
\text { reduction in } 3 \text { district } \\
\text { hospitals }\end{array}$ & $\begin{array}{l}\text { Malaria control } \\
\text { interventions }\end{array}$ \\
\hline Ifakara, Tanzania ${ }^{3}$ & 1995 to 2000 & $\begin{array}{l}\text { Incidence of malaria in }<5 \\
\text { year old children }\end{array}$ & $\begin{array}{l}\text { Reduced from } 0.8 \text { to } 0.43 \\
\text { episodes per child per year }\end{array}$ & $\begin{array}{l}\text { Economic improvements, } \\
\text { liberalisation of health } \\
\text { sector and malaria control } \\
\text { interventions }\end{array}$ \\
\hline Zanzibar, Tanzania ${ }^{4}$ & 2003 to 2006 & Parasite prevalence & $97 \%$ reduction & $\begin{array}{l}\text { Artemisinin Combination } \\
\text { Therapy and Insecticide } \\
\text { Treated Nets }\end{array}$ \\
\hline $\begin{array}{l}\text { Mozambique, South Africa } \\
\text { and Swaziland } 5\end{array}$ & $2000-2004$ & Parasite prevalence & $\begin{array}{l}>60 \% \text { fall in parasite } \\
\text { prevalence in all } 3 \text { zones } \\
\text { studied }\end{array}$ & Indoor residual spraying \\
\hline Guinea-Bissau6 & 1994 versus 2003/2004 & Parasite prevalence & $\begin{array}{l}\text { Reduced from } 44-79 \% \text { to } \\
3 \%\end{array}$ & $\begin{array}{l}\text { Untreated bed nets and } \\
\text { urbanisation }\end{array}$ \\
\hline Eritrea $^{7}$ & 2000 to 2004 & $\begin{array}{l}\text { Incidence of clinical malaria } \\
\text { and case fatality rate } \\
\text { reported by health facilities }\end{array}$ & $\begin{array}{l}\text { Decrease in malaria } \\
\text { incidence of } 83.3 \% \text { and case } \\
\text { fatality by from } 0.21 \text { to } \\
0.14 \%\end{array}$ & $\begin{array}{l}\text { Climate change and malaria } \\
\text { control methods (ITNs, IRS } \\
\text { and early case detection } \\
\text { and treatment) }\end{array}$ \\
\hline
\end{tabular}

decrease in cases in Southern Africa coincides with indoor residual spraying (IRS) programmes[5] but for the other reports there is no single clear intervention that could explain the declines. In Kenya it was noted that the decline started before the widespread use of insecticide-treated nets (ITNs)[2]. The decline appears to be broadly continent wide: there has been a reported decrease in the mean prevalence of Plasmodium falciparum parasites in cross-sectional surveys from 35\% between 1985 and 1999 to $20 \%$ since 2000[1]. Thus, the decline in malaria predates scaling-up of vector control measures including widespread use of ITNs. During the 1980s and 90s the mainstay of malaria control in Africa was presumptive treatment of fever with an anti-malarial. This strategy has been promoted by the Integrated Management of Childhood Illness (IMCI) and is adopted as policy in many developing countries[9]. In places where transmission is low or decreasing this strategy leads to over-diagnosis of malaria cases[10].

\section{Presentation of hypothesis}

The commonest drugs used for presumptive treatment of fever cases as malaria in the past 50 years of malaria control are chloroquine (CQ) and sulphadoxine-pyrimethamine (SP). Both these drugs have a long half-life and their efficacy and effectiveness for prophylaxis have been clearly documented[11]. Thus, treating most febrile illness with antimalarials, practiced widely in sub-Saharan Africa has lead to a mass and frequently applied treatment against malaria that not only cleared parasitaemia in true cases of malaria but also provided chemoprophylaxis for three weeks in the case of CQ and four weeks in the case of SP. We term this Opportunistic Presumptive Treatment (OPT).

The mechanism of OPT is to effectively treat those who are infected and prevent re-infection in both those who are and in those who are not infected. As most infections occur focally $[12,13]$, correctly treating these individuals clears active infection and prevents new infection in those most at risk of malaria. This in turn reduces the parasite burden in individuals and the infectious reservoir in the community. In low incidence areas, depending on frequency of treatment of fever as malaria, the community may be receiving enough anti-malarial prophylaxis to reduce transmission due to decreased carriage of parasites and thus, cause a gradual decline in malaria burden.

\section{Testing the hypothesis}

The likelihood is that the fall in malaria is multi-factorial with general economic development, climate change and malaria control strategies playing roles and identifying the role OPT has played is complex. However, as treatment of all fever cases remains standard practice in many endemic countries a longitudinal comparison of epidemiological parameters between current practice (OPT) and more targeted treatment of parasite positive febrile cases in the context of other control methods (e.g.ITN) should be undertaken. Strategies for evaluation could be (1) OPT with an ACT or non-ACT for all fever cases without any other obvious cause (current practice); (2) OPT plus an antibiotic for all fever cases; (3) ACT for confirmed cases 
of malaria (slide or rapid test positive) and OPT with non ACT plus an antibiotic for fever cases confirmed negative for malaria.

OPT has similarities to mass administration of antimalarial drugs (MDA). MDA for limited time periods has been tried for reducing transmission in the past without marked or sustained success[14]. However, OPT, given to individuals at high risk of carrying parasites for several years may have a different outcome than MDA. Since OPT is given to individuals who have a febrile illness an artemesinin in combination with a long-acting partner drug such as amodiaquine, mefloquine or piperiquine could be used. Artemesinins would act to reduce gametocyte carriage[15] while the long-acting partner drug would prevent new blood stage infections and thus new gametocyte production. Alternatively, non-ACTs using a combination of long acting drugs maybe preferred, thus saving the artemesinin component for treatment of proven disease, and these could be combined with gametocidal drugs such as primaquine or tafenoquine.

Programmes using long-acting drugs are at risk of inducing drug resistance. Both CQ and SP are no longer recommended for treating clinical malaria in Africa due to high levels of resistance. Combining long acting drugs and using high levels of vector control measures to reduce transmission of resistant strains may reduce the risk of drug resistance. Studies to evaluate the impact of OPT in combination with vector control measures on transmission of malaria, the emergence of drug resistance and costeffectiveness in Africa will be complex, large and expensive, and will require several years of follow up time. However, implementation of OPT would be relatively easy as the delivery mechanism is largely in place and the practise of presumptive treatment of fever is common amongst health professionals and the community.

\section{Implications of the hypothesis}

Currently OPT is delivered through the routine health care delivery system in most parts of Africa. Home management of malaria[16] is an extension of OPT in the communities. Due to pressures of over-diagnosis of malaria which has adverse outcomes for patients[10] and misinforms malaria control programmes, introduction of rapid diagnostic tests are being considered as a cost effective measure to improve the accuracy of diagnosis of malaria[17]. If the hypothesis is true, restricting antimalarial treatment to confirmed cases of malaria only will have little impact on control in high/moderate endemic settings as fewer people will be exposed to prophylactic levels of drugs. Treating fever cases confirmed as malaria with ACT and as non malaria with non-ACT OPT plus an antibiotic would circumvent this problem and have the added advantage of broadening syndromic management of fever to cover the most serious alternative diagnoses (i.e. bacterial sepsis). However, any widespread use of drugs will result in the community being exposed to drugs and their associated problems of side effects and drug resistance.

As transmission decreases there will be a point at which there is no benefit to be gained from treating asymptomatic carriers and preventing infection by prophylaxis. The level of transmission where changing strategies becomes advantageous is not known. However, when this point is reached active case detection and treatment plus surveillance for outbreaks would be the control method of choice.

Malaria remains a huge public health issue that needs the full armoury of current interventions. The good news is that, for whatever reason, malaria seems to be decreasing in many parts of sub-Saharan Africa. The recent call for eradication of malaria is timely and to achieve this aim all effective interventions need to be scaled up. In areas of moderate to high transmission mass over-treatment of fever as malaria (OPT) should be investigated as tool for malaria control. The major risk of this strategy is increasing drug resistance but the benefits may be much reduced malaria as is evident in parts of Africa.

\section{Authors' contributions}

All authors discussed and reviewed the ideas presented in the paper. All authors wrote the paper and read and approved the final version.

\section{Acknowledgements}

We thank Colin Sutherland for his insightful comments on the manuscript and the reviewers who improved the work. The work involved stimulating discussions with many people including Professor Chris Curtis who sadly passed away, Caroline Maxwell, Kevin Marsh, Brian Greenwood, Lorenz von Seidlein, Michala Vaaben Rose, Dr Samwel Gesase, Cally Roper and Azra Ghani to name but a few. RG is funded by the Bill and Melinda Gates Foundation, $C D$ is funded by the Wellcome Trust, $A M$ is funded by the Government of Tanzania and DC is funded by the London School of Hygiene and Tropical Medicine. All authors state no conflict of interest.

\section{References}

I. Guerra CA, Gikandi PW, Tatem AJ, Noor AM, Smith DL, Hay SI, Snow RW: The limits and intensity of Plasmodium falciparum transmission: implications for malaria control and elimination worldwide. PLoS Med 2008, 5(2):e38.

2. Okiro E, Hay SI, Gikandi PW, Sharif SK, Noor A, Peshu N, Marsh K, Snow RW: The decline in paediatric malaria admissions on the coast of Kenya. Malaria Journal 2007, 6(I5I):. doi:I0.1186/ |475-2875-I| |86-| I5 |.

3. Schellenberg D, Menendez C, Aponte J, Guinovart C, Mshinda H, Tanner $\mathrm{M}$, Alonso $\mathrm{P}$ : The changing epideimology of malaria in Ifakara Town, Southern Tanzania. Tropical Medicine and International Health 2004, 9(I):68-76.

4. Bhattarai A, Ali AS, Kachur P, Martensson A, Abbas AK, Khatib R, Almafazy A, Ramsan M, Rotllant G, Gerstenmaier JF, Molteni F, Abdulla S, Montgomery SM, Kaneko A, Bjorkman A: Impact of artemesinin- based combination therapy and insecticide- treated nets on malaria burden in Zanzibar. Plos Medicine 2007, 4(I I):e309. 
5. Sharp B, Kleinschmidt I, Streat E, Maharaj R, Barnes K, Durrheim DN, Ridl FC, Morris N, Seocharan I, Kunene S, La Grange JJP, Mthembu JD, Maartens F, Martin CL, Barreto A: Seven years of regional malaria control colaboration- Mozambique, South Africa and Swaziland. Am J Trop Med Hyg 2007, 76(I):42-47.

6. Rodrigues A, Armstrong Schellenberg J, Kofoed PE, Aaby P, Greenwood B: Changing pattern of malaria in Bissau, Guinea Bissau. Trop Med Int Health 2008, 13(3):4I0-4I7.

7. Nyarango PM, Gebremeskel T, Mebrahtu G, Mufunda J, Abdulmumini U, Ogbamariam A, Kosia A, Gebremichael A, Gunawardena D, Ghebrat $\mathrm{Y}$, Okbaldet $\mathrm{Y}$ : A steep decline of malaria morbidity and mortality trends in Eritrea between 2000 and 2004: the effect of combination of control methods. Malar J 2006, 5:33.

8. Roberts L, Enserink M: Did they really say ... Eradication. Science 2007, 3 I 8: I545-I546.

9. Integrated Management of Childhood IIIness (IMCI) [http:// www.who.int/child adolescent health/topics/prevention care/child/ imci/en/]

10. Reyburn H, Mbatia R, Drakeley C, Carneiro I, Mwakasungula E, Mwerinde O, Saganda K, Shao J, Kitua A, Olomi R, Greenwood B, Whitty CJM: Overdiagnosis of malaria inpatients with severe febrile illness in Tanzania: a prospective study. BMJ 2004, 329: 1212 .

II. Winstanley P, Ward S: Malaria chemotherapy. Adv Parasitol 2006, 6I:47-76.

12. Yazoume Y, Kyotbutungi C, Louis VR, Sauerborn R: Micro-epidemiology of Plasmodium falciparum malaria: Is there any difference in transmission risk between neighbouring villages? Malar J 2007, 6(46):. doi: I0.1 I 86/I475-2875-|476-I446.

13. Mwangi TW, Fegan G, Williams TN, Kinyanjui SM, Snow RW, Marsh $\mathrm{K}$ : Evidence for over-dispersion in the distribution of clinical malaria episodes in children. PLoS ONE 2008, 3(5):e2196.

14. von Seidlein L, Greenwood BM: Mass administrations of antimalarial drugs. Trends Parasitol 2003, I 9( I0):452-460.

15. Price RN, Nosten F, Luxemburger C, ter Kuile FO, Paiphun L, Chongsuphajaisiddhi $T$, White $N$ J: Effects of artemisinin derivatives on malaria transmissibility. Lancet 1996, 347(90 I6): I654-I658.

16. Hopkins H, Talisuna A, Whitty CJ, Staedke SG: Impact of homebased management of malaria on health outcomes in Africa: a systematic review of the evidence. Malar J 2007, 6:134.

17. Shillcutt S, Morel C, Goodman C, Coleman P, Bell D, Whitty CJ, Mills A: Cost-effectiveness of malaria diagnostic methods in subSaharan Africa in an era of combination therapy. Bull World Health Organ 2008, 86(2): I0I-II0.

Publish with Bio Med Central and every scientist can read your work free of charge

"BioMed Central will be the most significant development for disseminating the results of biomedical research in our lifetime. "

Sir Paul Nurse, Cancer Research UK

Your research papers will be:

- available free of charge to the entire biomedical community

- peer reviewed and published immediately upon acceptance

- cited in PubMed and archived on PubMed Central

- yours - you keep the copyright

Submit your manuscript here:

http://www.biomedcentral.com/info/publishing_adv.asp
BioMedcentral 